\title{
THE RELATIONSHIP BETWEEN THE DEVELOPMENT OF THE FINANCIAL SECTOR AND THE ECONOMIC GROWTH IN THE REPUBLIC OF NORTH MACEDONIA
}

\author{
Dashmir Saiti \\ Faculty of Economics - Skopje, Ss. Cyril and Methodius University \\ dashmirs@gmail.com \\ Borce Trenovski \\ Faculty of Economics - Skopje, Ss. Cyril and Methodius University \\ borce.trenovski@eccf.ukim.edu.mk
}

\begin{abstract}
According to economic theory, the money supply positively affects economic growth, especially in the short run. Additionally, for small and open economies, the openness of the economy plays a crucial role in economic growth. Therefore, the subject of this paper is the impact of the money supply, measured through the broad money aggregate (M3), and trade openness of the country on the economic growth in North Macedonia. M3 aggregate is taken as an indicator of the financial sector development, whereas on the other hand, the trade-to-GDP ratio is an indicator for the openness of the economy. The research is employing the Vector Autoregression (VAR) model, and quarterly data for the period 1995-2019 are used. As opposed to the economic theory, the results show the absence of a long-run relationship between GDP, broad money, and trade openness in North Macedonia for the observed period. Also, in the short run, M3 and trade openness have a significant positive impact on GDP. Additionally, there is no noticeable time gap in the above relationships. Namely, the impact of broad money and trade openness on GDP in North Macedonia is not much stronger after a significant time lag from the impact in the first year. This put into question the capability of the monetary policy as a tool of the broader macroeconomic policy to shift the aggregate demand curve upwards and boost economic activity.
\end{abstract}

Keywords: Financial Development, Trade Openness, Economic Growth, VAR

JEL Classification: E51, F1, F43

\section{INTRODUCTION}

Financial development is a basic determinant of economic growth in a national economy. For small and open economies, a key role for economic growth is the openness of the economy. As a proxy in economic theory for the measure of financial development is the ratio of money supply to gross domestic product, which ratio should have a stable growth of the broad money aggregate and economic growth, also a key issue is managing trade openness, which is ratio of the sum of imports and exports to GDP. Financial development is important for economic growth because it mobilizes savings and helps with capital accumulation, it is a process of strengthening the quantity and quality of financial intermediation services, where in fact, the modern financial environment encompasses a wide range of activities such as trade, risk pooling, hedging, etc. (Haque, 2020).

The relationship between trade liberalization, financial reform and economic growth is well documented in the economic literature, where it is argued that trade policies and financial liberalization reduce inefficiencies in the production process and positively affect economic growth, where this argument is reinforced by the fact that countries with more open trade and financial policies can grow faster than those with limited trade and financial policies (Khan \& Qayyum, 2007). This is widely evident from the fact that countries with a high degree of trade 
openness and a well-developed financial system have higher GDP growth compared to countries with a low financial sector for development and restrictive trade policies (Murthy, et al., 2014). Opening to trade will affect demand for external finance, and thus financial depth, in the trading countries, when a wealthy country starts trading with a poor one, it will naturally increase production of the financially dependent good, and its financial system will deepen, on the other hand, in the poor country the financially dependent sector will shrink, leading to a deterioration in the size of the country's financial system, as well as its quality (Quy-Toan \& Levchenko, 2004).

Many different researches and models in the past period have been observed to find the economic implications of trade openness and its impact on economic growth. In the Republic of North Macedonia, in the past 25 years, there is a continuous trend of increasing the share of trade and money supply as a percentage of GDP. Hence, the subject of this research is the relationship between the broad money aggregate (M3), as a financial indicator, and the trade openness of the nominal gross domestic product in North Macedonia in the period from 1995 to 2019. The assumption is that these two variables have a statistically significant impact on the nominal GDP in Republic of North Macedonia (RNM).

Early contributions used aggregate bank data for a number of developed and developing countries, including the ratio to GDP of monetary variables (M2 or M3) or indicators of financial depth (loans to the private sector), but later studies on the relationship between financial Development and economic growth have also added indicators of stock market size and liquidity, but they are available for fewer countries and for a shorter period of time, and variables such as the ratio of broad money to GDP are taken as a measure of the size of the financial sector (Caporale, et al., 2009). Monetary policy plays a significant role in boosting any country's economic growth, there has been a long debate in the economy about the role of money in the economy, where "Monetarists" believe that monetary policy affects prices but not real GDP, or unemployment, while Keynesians believe that changes in the money supply led to changes in real output and prices (Chaitipa, et al., 2015).

Contemporary research practices in the empirical literature tend to focus on the short and long run dependencies and mutual implications between economic growth and development of the financial sector. However, there is no clear consensus weather long run relationship between these two phenomena exists or not. In this regard, the research employs dynamic time series models, whereby special attention is devoted to the existence of potential long run relationship, since it is of high importance for the overall econometric analysis.

The research paper is structured in three sections. First section reviews the relevant empirical literature of impact of financial development and trade openness on economic activity. The second part analyzes the methodology and data for the endogenous variables of interest, the stability test of the variables, and the Johansen test for cointegration. Finally, the third part summarizes the results and discussion of financial and economic activity through their comparisons of mean values, correlation, causality, variance decomposition, and impulse response in the Republic of North Macedonia.

\section{LITERATURE REVIEW}

Various studies have explored the relationships and effects of financial development and trade openness and their impact on economic growth in the short and long term. Popov (2017), reviews and evaluates the empirical research on the relationship between financial markets and economic growth, accumulated in the last quarter of the century, where most of the historical evidence suggests that financial development causes economic growth in a positive and monotonous way. According to Rajan \& Zingales (2001), they show that the development of the financial sector does not change monotonously over time, in particular, they find that according to most measures, countries were more financially developed in 1913 than in 1980 
and emphasize, among other things, that trade openness correlates with the development of the financial market, especially when cross-border capital flows are free.

Empirical analyzes that concluded that financial development has a long-term and positive relationship with economic growth, for instance, Levine (1997), Khan \& Qayyum (2007), Shahbaz \& Rahman (2012), Ewetan \& Okodua, (2013), Tsaurai (2017), Chandrashekar et al., (2018) and Obeid \& Awad (2018), on the other hand, the short-term positive impact is confirmed by the research of Caporale et al. (2009) and weak causality by (Murthy, et al., 2014). Broad money supply and economic growth show a significant long-term and positive relationship by Sultana (2018) and short-run causality between money supply (M3) and GDP (Bednarik, 2010; Simionescu, et al., 2018). The findings showed that financial development has a negative effect on growth in long-run, according to Yucel (2009), the presence of structural breaks indicate a stable long-run with the negative link, according to Elijah \& Hamza (2019) and, in the case of the short run, broad money supply have negative effects on economic growth (Sultana, 2018). Some studies have also found that there is bidirectional causality between financial development and economic growth (Lewis, 1995; Demetriades \& Hussein, 1996; Baliamoune-Lutz, 2013; Murthy, et al., 2014; KAR, et al., 2014; Simionescu, et al., 2017). Trade openness has a positive significant impact on economic growth and the results also show that trade openness is the significant driving force for growth in the long run (Khan \& Qayyum, 2007; Yucel, 2009; Shahbaz, 2012; Tsaurai, 2017; Obeid \& Awad, 2018; Chandrashekar, et al., 2018; Nwadike, et al., 2020).

Ariç (2014), analyzes the relationship between financial development and economic growth in the European Union using the panel data method, which includes the period between 2004 and 2012. According to the relevant research, the ratio of capitalization, money and quasi-money M2 as (\%) of GDP have a positive impact on growth, while domestic credit to the private sector as $(\%)$ of GDP has a negative impact on growth.

According to Dingela \& Khobai (2017) investigates the dynamic impact of broad money supply (M3) on economic growth (GDP) per capita in South Africa using time-series data from 1980 to 2016, the study used the autoregressive distributed lag (ARDL)-bounds testing approach to cointegration and error correction model to examine the impact of (M3) on GDP per capita. The results show that there is a statistically significant positive relationship between money supply and economic growth in the short and long term.

Yugang (2017) shows that many scholars have researched the importance of money supply in macroeconomics in developed countries, while few studies have explored it in developing countries. Yugang's research refers to the data of the annual series from 2000 to 2016 in China to analyze the relationship between money supply (M2) and macroeconomic variables using the vector auto regression (VAR) model. Among other results is and the following result that an increase in real GDP could result in an increase in the money supply.

In the study by Hussain \& Haque (2017) assessed the impact of the relationship between money supply and GDP growth per capita in Bangladesh from 1974 to 2014 using the VECM model. They specified the model with three variables, the percentage of broad money to GDP, real interest rates and the annual GDP growth rate per capita. The results suggest that a stable percentage of broad money is related to the growth rate and on the other hand, money supply has a significant impact on the growth rate of output in the long run. According to the relevant research, it is recommended that the government maintain consistency and follow the "the Taylor rule" to allow the money supply to grow at a steady rate in line with economic growth. The main purpose of the research of Simionescu et al. (2018) is to evaluate the relation between GDP and the most important monetary variables in two countries: Romania and the Czech Republic over the period of 1995:Q1 - 2015:Q4 and in the empirical part were applied the vector error correction models (VECM). The main findings are the following: in Romania and in the Czech Republic there is a short-run causality from money supply (M3) to GDP and a 
long-run relationship between GDP, internal credit, and M3, the rate of M3 was a cause of economic growth in Romania, it was not confirmed for the Czech Republic.

Asteriou \& Spanos (2019) examined the relationship between financial development and economic growth on the face of the recent financial crisis, using a panel dataset of 26 European Union countries over the period 1990-2016. The relevant empirical research uses multiplicative dummies to compare two distinct sub-periods before and after the crisis, where the results show that before crisis, financial development promoted economic growth, while after the crisis it hindered economic activity. The study of Ginevičius et al. (2019) examined the relationship between financial and economic development in the countries of the European Union using annual data for the period 1998-2016, the authors did this by reviewing descriptive statistics and also by applying econometric methods. The Granger causality test showed that the authors found: (1) countries with an average GDP per capita indicator showed the highest level of financial development; (2) in Denmark, Portugal and Latvia, unidirectional causality has been discovered, from real GDP to financial development; (3) unidirectional causality running from financial development to real GDP has been found in Austria; (4) two-way causal links between financial and economic development have been identified in Luxembourg, France and the United Kingdom; (5) results from Finland, Germany, the Czech Republic, Slovakia, Croatia and Bulgaria supported the neutrality approach.

The research of Elijah \& Hamza (2019) explores the relationship between financial sector development and economic growth in Nigeria, using annual time series data for the period 1981 to 2015. They examine the long-term relationship between financial sector development and economic growth through cointegration with endogenous structural break and VECM modeling. The results show that there is a co-integration between financial development, trade openness and economic growth with structural breaks in 2010 and the model reveal that there is a significant negative relationship between financial development and economic growth during the research period.

The study of Gries \& Redlin (2012) was focused on the short-term and long-term dynamics between GDP growth per capita and trade openness to 158 countries in the period 1970-2009, using panel cointegration tests and panel error-correction models (ECM) in combination with GMM estimation. Furthermore, they applied Difference GMM and System GMM estimations. According to their results, long-term coefficients indicate a positive significant causality from openness to growth and vice versa, in contrast, the short-term coefficient shows a negative short-term adjustment, which suggesting that openness can be painful for an economy undergoing short-term adjustments.

Murthy et al. (2014) examined the correlation and direction of causality between the three macroeconomic variables such as trade liberalization, financial development, and economic growth in India using Johansen's co-integration test and the VECM for the direction of longterm causality. This study also found that there is bidirectional causality between financial development and growth, however, causality deriving from growth to finance is stronger than that from finance to growth, and unidirectional causality ranging from financial development and economic growth to open trade. Chandrashekar et al. (2018) examine the relationship between financial development, trade openness, and economic growth in India, using the Phillips-Perron (PP) test, Johansen's co-integration, and Granger causality methodology for the long-run relationship and direction of Causality between variables for the period from 19752014. Their findings confirm that there is a long-term link between financial development, trade openness, and growth, and causality results in a mixed direction.

In the case of single-country studies, Obeid \& Awad (2018) they explored the effect of trade openness and financial development on economic growth in Jordan based on quarterly data for the period (1992-2015). According to their research, two forms were used for measuring the effect of trade openness on economic growth using the Autoregressive Distributed lag model, 
the results showed that there exists a long-term positive effect of trade openness and financial development on economic growth in Jordan and on another side, for the short-term impact, the effect of trade openness and financial development on economic growth was not statistically significant.

Wajda-Lichy et al. (2019) examined the causality between trade openness and financial development in 11 new member states of the European Union using the Granger panel approach. According to their research, the main findings are as follows: (1) the test results of the finance-trade nexus are country-specific; (2) statistically significant causality is found from trade to finance in eight countries (Bulgaria, Estonia, Hungary, Latvia, Lithuania, Poland, Romania, and Slovenia); (3) finance is a statistically significant reason for causality to trade in six countries (Croatia, Estonia, Latvia, Lithuania, Poland, and Slovakia), and in four of them (Croatia, Estonia, Latvia, Lithuania), the regression coefficients positive signs, which support the supply-leading.

\section{DATA AND METHODOLOGY}

The research uses data from the IMF (International Monetary Fund) and WB (World Bank) databases on the nominal GDP of the Republic of North Macedonia, the broad money supply (M3) as a percentage of GDP, and trade openness also as a percentage of GDP, for the period 1995 to 2019. This selection of the variables finds strong support in the classical economic theory based on money neutrality, which assumes that changes in the total money supply affect the nominal variables rather than the real ones (Hussain \& Haque, 2017). In addition, the model follows the work of Elijah \& Hamza (2019), which investigate the effects of financial sector development on economic growth, whereby financial development is measured by the broad money supply-to-GDP ratio, economic growth is represented by the natural logarithm of the nominal GDP, whereas openness, as control variable, is represented by the ratio of the sum of exports and imports divided by the nominal GDP.

According to the National Bank of the Republic of North Macedonia (2017), broad money M1 is the currency in circulation and demand deposits, broad money M2 includes the monetary aggregate M1 and the short-term deposits and broad money M3 (standardized definition of broad money) includes the monetary aggregate M2 and long-term deposits with maturity from one to two years.

The data for nominal GDP are on a quarterly basis, while for M3 and trade openness on an annual basis, by transforming them on a quarterly basis using Eviews software, using the cubic method. This transformation aims to provide a larger statistical sample, since the real data available on these variables are insufficient for reliable estimation of the developed VAR model. Furthermore, because the variables used are on a quarterly basis and the seasonal influence in their movement is visible, they are further seasonally adjusted through the census method X-12 (additive). Additionally, due to the fact that the original values of the nominal GDP are in absolute amount, its logarithmic transformation has been performed. Possible limitation in this regard is that using interpolated data in the analysis might result in biased estimates, caused by spurious relationships. This limitation should be taken into consideration when interpreting the obtained results, as well as for further research.

Because the analysis is based on time series, in which there is a deterministic trend, the PhillipsPerron unit root test is used to determine their order of integration. The result of this test shows that all variables are non-stationary of the first order, which can be seen from (Table 1), where the $\mathrm{p}$-values of the conducted test are shown. 
Table 1: Testing for unit roots

\begin{tabular}{|c|c|c|c|c|}
\hline \multirow{2}{*}{ Variable } & \multirow{2}{*}{ Included in the test } & \multicolumn{2}{|c|}{ Phillips-Perron } & \multirow{2}{*}{$\begin{array}{c}\text { Order of } \\
\text { identification }\end{array}$} \\
\hline & & level & 1st difference & \\
\hline \multirow{3}{*}{ lgdp_q_sa } & Intercept & 0.9287 & 0.0001 & \multirow{3}{*}{$\mathrm{I}(1)$} \\
\hline & Trend and intercept & 0.0241 & 0.0000 & \\
\hline & None & 1.0000 & 0.0000 & \\
\hline \multirow{3}{*}{ broad_m_q_sa } & Intercept & 0.6003 & 0.0032 & \multirow{3}{*}{$\mathrm{I}(1)$} \\
\hline & Trend and intercept & 0.9582 & 0.0313 & \\
\hline & None & 0.9966 & 0.0014 & \\
\hline \multirow{3}{*}{ trade_q_sa } & Intercept & 0.9243 & 0.0019 & \multirow{3}{*}{$\mathrm{I}(1)$} \\
\hline & Trend and intercept & 0.1063 & 0.0125 & \\
\hline & None & 0.9621 & 0.0003 & \\
\hline
\end{tabular}

(Source: Authors' calculation)

Additionally, with the help of the Johansen (1991) cointegration test, for 3 lag intervals, it was determined that there is no statistically significant long-run relationship between the variables (cointegration) (Table 2). Hence, the most appropriate way to model them would be a VAR model with differentiated series (Yugang, 2017). The VAR model is used when there is no cointegration between variables and is estimated using time series that are transformed into their stationary values (Altaee, et al., 2014).

Table 2: Johansen cointegration test - Unrestricted Cointegration Rank Test (Trace)

\begin{tabular}{|c|c|c|c|c|}
\hline $\begin{array}{c}\text { Hypothesized } \\
\text { No. of CE(s) }\end{array}$ & Eigenvalue & $\begin{array}{c}\text { Trace } \\
\text { Statistic }\end{array}$ & $\begin{array}{c}0.05 \text { Critical } \\
\text { Value }\end{array}$ & Prob.** \\
\hline None & 0.136728 & 17.57505 & 29.79707 & 0.5975 \\
\hline At most 1 & 0.039636 & 3.901665 & 15.49471 & 0.9113 \\
\hline At most 2 & 0.001509 & 0.140484 & 3.841466 & 0.7078 \\
\hline Trace test indicates no cointegration at the 0.05 level \\
\hline * Denotes rejection of the hypothesis at the 0.05 level \\
\hline **MacKinnon-Haug-Michelis (1999) p-values \\
\hline
\end{tabular}

(Source: Authors' calculation)

Regarding the number of lag intervals, since the data are on a quarterly basis, the optimal number would be 4 or 8 lag intervals, which corresponds to a time period of 1 and 2 years of time lags, respectively. If some statistical indicators are taken into account, such as information criteria and indicators for the suitability and reliability of the models, it is determined that the optimal number of lag intervals in the model is 4 . Additionally, due to the fact that by differentiating the series one of these 4 lags intervals is lost, in the previously mentioned cointegration test, as well as in the evaluation of the VAR model, 3 time lags are included, i.e. one less than the optimal 4.

The VAR model can be represented by the equations of GDP, M3 as (\%) of GDP and trade openness as (\%) of GDP. The set of equations for all three endogenous variables represented the VAR model. In mathematical form the equations of autoregressive model are represented for the three endogenous variables, where $\beta_{1}, \beta_{2}$ and $\beta_{3}$ are the coefficients of the short-term connection blocks for the three variables consequently for $\mathrm{p}$ or 3 time lags and $\beta_{0}$ represents the intercept coefficient and $u_{n}$ random error. 
$\Delta l o g g d p_{-} q_{-} s a=\beta_{0.1}+\beta_{1 . p .1} \sum_{p=1}^{3} \Delta l o g g d p_{-} q_{-} s a_{t-p}+\beta_{2 . p .1} \sum_{p=1}^{3} \Delta b r o a d \_m \_q_{-} s a_{t-p}+$ $\beta_{3 . p .1} \sum_{p=1}^{3} \Delta$ trade_q_sa $a_{t-p}+u_{1}$

$\Delta b r o a d \_m \_q \_s a=\beta_{0.2}+\beta_{1 . p .2} \sum_{p=1}^{3} \Delta l o g g d p_{-} q \_s a_{t-p} \beta_{2 . p .2} \sum_{p=1}^{3} \Delta b r o a d \_m_{-} q_{-} s a_{t-p}+$ $\beta_{3 . p .2} \sum_{p=1}^{3} \Delta t r a d e_{-} q_{-} s a_{t-p}+u_{2}$

$\Delta t r a d e_{-} q_{-} s a=\beta_{0.3}+\beta_{1 . p .3} \sum_{p=1}^{3} \Delta l o g g d p_{-} q_{-} s a_{t-p}+\beta_{2 . p .3} \sum_{p=1}^{3} \Delta b r o a d \_m_{-} q_{-} s a_{t-p}+$ $\beta_{3 . p .3} \sum_{p=1}^{3} \Delta t r a d e \_q \_s a_{t-p}+u_{3}$

The VAR model thus laid is the basis for conducting the Granger (1974) causality test, the impulse response function and the analysis of variance, which would determine the presence and strength of the relationship between the observed variables.

\section{RESULTS OF THE ECONOMETRIC ANALYSIS}

The broad money (M3) in the Republic of North Macedonia, in the period from 1995 to 2019, records a continuous positive trend, the dynamics of which slightly decreases after 2008. There is also a positive trend in trade openness, with some structural disruptions also observed in the period of the global financial crisis of 2008. The movement of these two variables, as well as the nominal GDP in the Republic of North Macedonia, is shown in (Figure 1) below. It can be seen that the lowest ratio between M3 and GDP was recorded in the first years of transition in 1995 and 1996 with $11 \%$, while the highest ratio is observed in 2019 with 58\%. Trade openness, expressed as (\%) of GDP, reached its lowest level in 1996, while in 2019 it reached the highest $137 \%$ of GDP.

Figure 1: Broad money movement, trade openness and nominal GDP in RNM

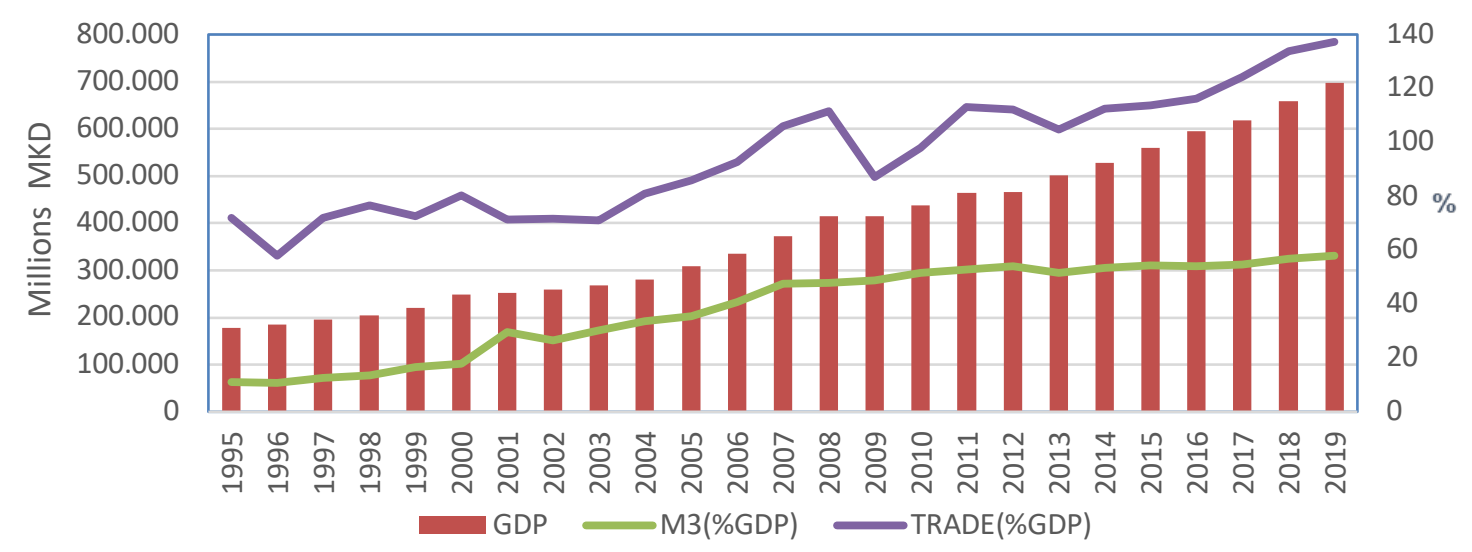

(Source: Authors' illustration)

If we look at the average values of trade openness and money supply before and after 2008, the difference is noticeable, i.e., the increase in the post-crisis period. Namely, the share of broad money aggregate (M3) in GDP before and after the global crisis is growing almost twice, from $25 \%$ to $49 \%$, while trade openness is growing from $78 \%$ to $105 \%$. These are statistically significant differences confirmed by the ANOVA test. Because of its ease of use, closeness, and clear interpretation, researchers will sometimes refer to the comparison of group means on several dependent variables using a series of independent univariate Analysis of Variance (ANOVA) models (Finch, 2016).

The positive relationship between money supply and GDP of which they speak Korauš et al. (2017), i.e., the openness of trade and GDP they are talking about Huchet et al. (2018), is also confirmed in the case of the Republic of North Macedonia, where the correlation coefficients 
between these variables are over 0.95. According to Levine (2003) various studies and their mutual comparisons have demonstrated a strong and positive relationship between the functioning of the financial system and long-term economic growth. According to Elijah \& Hamza (2019), it is recommended that in order to achieve the desired level of economic growth through financial development we should take into account the structural breaks in the macroeconomic empirical analysis as it helps to avoid false results and financial development should be supported by other proactive measures to complement reforms in the financial sector. Regarding the set VAR model, it is statistically significant and fully meets the assumptions of the classical linear regression model, including the stationarity requirement. The model is well adjusted, with the adjusted coefficient of the determination being 0.17 for the GDP equation, 0.97 for the broad money equation (M3), and 0.98 for the trade openness equation. Additionally, the model has a small prediction error, the Mean Absolute Percentage Error (MAPE) is below 1\%, indicating that it is on a solid footing for reliable results. During the analysis of the diagnostics of the residuals, it is noticed that in the three models there is no presence of the first-order autocorrelation with the application of the Breusch-Godfrey Serial Correlation LM Test. In the equation of nominal GDP, the residuals do not have the presence of heteroskedasticity by applying the White Test. The evaluated model has three endogenous variables from which no inverse root is outside the limits of the inverse root circle and the model satisfies the stable state. Based on the estimated model, the Granger causality test shows that broad money aggregate (M3) has a short-term impact on nominal GDP, but not vice versa. There is only a unidirectional statistically significant relationship between trade openness and nominal GDP, i.e., trade openness has a short-term impact on GDP, but not vice versa (Table 3). Following the short-term causality of M3 and trade openness, it is noticed that there is only one short-term relationship, where the M3 has a short-term relationship on trade openness at the level of statistical significance of 0.05 , but not vice versa.

\section{Table 3: Granger causality test}

\begin{tabular}{|c|c|c|c|c|}
\hline & \multicolumn{4}{|c|}{ Dependent } \\
\hline \multirow{4}{*}{ 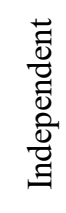 } & variables & $\Delta \operatorname{lgdp\_ q\_ sa}$ & $\Delta$ broad_m_q_sa & $\Delta$ trade_q_sa \\
\hline & $\Delta \operatorname{lgdp\_ q\_ sa}$ & l & 4.84 & 2.87 \\
\hline & $\Delta$ broad_m_q_sa & $7.59 *$ & l & $9.33 * *$ \\
\hline & $\Delta$ trade $\mathrm{q}$ sa & $7.64 *$ & 1.92 & l \\
\hline
\end{tabular}

Gries \& Redlin (2012) examine the cause-and-effect relationship between trade openness to GDP, whereby the lower-income panel countries show a negative causality, the high-income countries show a positive relationship between growth and trade openness, the desired growthled openness and openness-led growth hypothesis can only be supported for industrialized countries.

If the variance of the nominal GDP is decomposed as an endogenous variable in the estimated VAR model, it can be seen that broad money (M3), for 10 periods explains about $3 \%$ of the variations in nominal GDP, with its impact not increasing throughout the period. On the other hand, trade openness has a consequent impact on GDP, where it has little impact on nominal GDP. During the 10 periods, trade openness explains about $3 \%$ of the variations in nominal GDP.

When analyzing the accumulated impulse response of the dependent variable (lgdp_q_sa), (Figure 2), it can be seen that a shock to the broad money supply (M3) will cause positive 
effects on GDP starting after the fifth period, with a tendency to increase until the ninth period, followed by stagnation and a tendency for a slight decrease in the impact until the tenth period. On the other hand, a shock to trade openness from the first period will cause a positive slight increase in GDP until the sixth period or up to a year and a half, where subsequently the positive effect decreases to the ninth period and is followed by stagnation of the impact on GDP.

Figure 3: Impulse response to nominal GDP

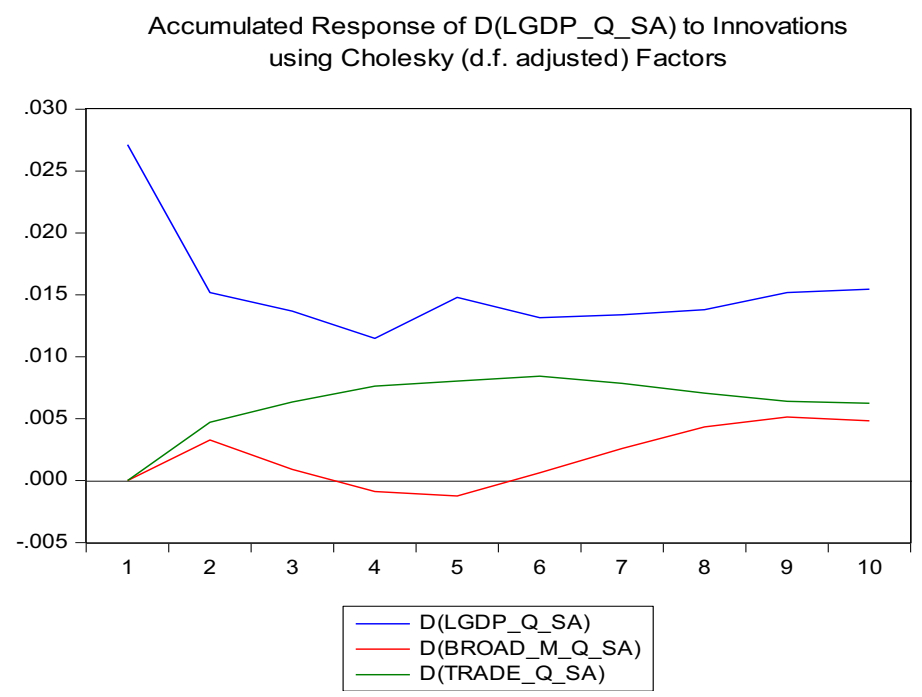

(Source: Authors' illustration)

From the aspect of the stability of the system, the function of the non-accumulated impulse response shows that the nominal GDP in the Republic of North Macedonia is relatively durable when it comes to shocks to endogenous variables. Namely, after the initial shock that would occur in response to the nominal GDP for a shock of a standard deviation in the other variables is absorbed relatively quickly, after which the system returns to its long-term equilibrium. In other words, the broad money supply and trade openness in the Republic of North Macedonia does not represent a risk factor that could lead to permanent structural shifts in nominal GDP.

\section{CONCLUSION AND DISCUSSION}

According to the results of the conducted research, it can be concluded that the financial component M3 / GDP has a statistically significant short-term and positive impact on the nominal GDP in the Republic of North Macedonia. Although there is a strong linear relationship between the two variables, it can be concluded that the growth dynamics is higher in money supply than in GDP. This results in a significantly higher average level of M3 as a percentage of GDP in the post-crisis period (49\%) than in the pre-crisis period $(25 \%)$. However, the money supply explains a relatively small part of the nominal GDP in the Republic of North Macedonia, i.e., about 3\%. Additionally, given that in the first periods the impact of the money supply is linear (about 3\%), it testifies to a possible time lag in the effects that money supply has on the overall economy. From an economic point of view, this result calls into question the effectiveness of the overall monetary policy in the country, primarily from the aspect of its use in order to stimulate economic activity and raise the aggregate demand curve. On the other hand, unlike the experiences of many other countries, trade openness has a statistically significant short-term and positive impact on nominal GDP. Namely, it explains only about $3 \%$ of the variations in GDP, which indicates that there are other dominant sectors that drive the output in the country. In addition, trade openness is an indicator of the country's 
integration into international markets. Hence, this result may mean that the Republic of North Macedonia has not yet reached its potential in that regard. According to the economic literature, countries with more open trade and financial policies can experience faster economic growth, since it is believed that trade policies and financial liberalization reduce inefficiencies in the production process. It is important to emphasize that the conducted analysis focuses only on one aspect in the interrelationship of the observed variables. Therefore, the indications regarding the effectiveness of the monetary policy and the development of the financial sector, as well as regarding the foreign trade integration of the country can be taken as a basis for further, more detailed analysis.

\section{REFERENCES}

Altaee, H., Saied, S., Esmaeel, E. \& Adam, M., (2014), "Financial Development, Trade Openness and Economic Growth: Evidence from Sultanate of Oman (1972-2012)", Journal of economics and sustainable development, Volume 5, pp. 64-75.

Ariç, K. H., (2014), "The Effects of Financial Development on Economic Growth in the European Union: A Panel Data Analysis", International Journal of Economic Practices and Theories, 4(4).

Asteriou, D. \& Spanos, K., (2019), "The relationship between financial development and economic growth during the recent crisis: Evidence from the EU", Finance Research Letters, Elsevier, 28(C), pp. 238-245.

Baliamoune-Lutz, M., (2013), Financial Development and Income in African Countries. Contemporary Economic Policy, 31(1), pp. 163-175.

Bednarik, R., (2010), Money Supply and Real GDP: The Case of the Czech Republic, Available at: https://ssrn.com/abstract $=1539390$ [Accessed: 15. 07. 2021].

Caporale, G. M., Rault, C., Sova, R. \& Sova, A., (2009), "Financial Development and Economic Growth: Evidence from Ten New EU Members", Discussion Papers of DIW Berlin 940, DIW Berlin, German Institute for Economic Research.

Chaitipa, P., Chokethaworn, K., Chaiboonsri, C. \& Monekeo, (2015), "Money Supply Influencing on Economic Growth-wide Phenomena of AEC Open Region", Procedia Economics and Finance, Volume 24, pp. 108-115.

Chandrashekar, R., Sampath, T. \& Chittedi, K. R., (2018), "Financial development, trade openness and growth in India", Theoretical and Applied Economics, Spring, XXV, No. 1(614), pp. 113-124.

Demetriades, P. O. \& Hussein, K. A., (1996), Does financial development cause economic growth? Time-series evidence from 16 countries, Journal of Development Economics, Volume 51, pp. 387-411.

Dingela, S. \& Khobai, H., (2017), "Dynamic Impact of Money Supply on Economic Growth in South Africa. An ARDL Approach", MPRA Paper No. 82539, University Library of Munich, Germany.

Elijah, S. \& Hamza, N., (2019), "The Relationship between Financial Sector Development and Economic Growth in Nigeria: Cointegration with Structural Break Approach", International Journal of Engineering and Advanced Technology (IJEAT), 8(5C).

Ewetan, O. O. \& Okodua, H., (2013), "Is There a Link Between Financial Sector Development and Economic Growth in Nigeria?", International Journal of Financial Economics, 1(4), pp. 108-118.

Finch, W., (2016), "Comparison of Multivariate Means across Groups with Ordinal Dependent Variables: A Monte Carlo Simulation Study", Front. Appl. Math. Stat., 2(2).

Ginevičius, R., Dudzevičiūtè, G., Schieg, M. \& Kęstutis, (2019), "The inter-linkages between financial and economic development in the European Union Countries", Economic ResearchEkonomska Istraživanja, 32:1, pp. 3315-3332. 
Granger, C. \& Newbold, P., (1974), "Spurious Regressions in Econometrics", Journal of Econometrics, 2(2), pp. 111-120.

Gries, T. \& Redlin, M., (2012), "Trade Openness and Economic Growth: A Panel Causality Analysis", Working Papers CIE 52, Paderborn University, CIE Center for International Economics.

Haque, M. I., (2020), "The Growth of Private Sector and Financial Development in Saudi Arabia", Economies, MDPI.

Huchet, M., Mouël, C. L. \& Vijil, M., (2018), "The relationship between trade openness and economic growth: Some new insights on the openness measurement issue", The World Economy, Wiley, 41 (1), pp. 59-76.

Hussain, M. E. \& Haque, M., (2017), "Empirical Analysis of the Relationship between Money Supply and Per Capita GDP Growth Rate in Bangladesh", Journal of Advances in Economics and Finance, 2(1).

Johansen, S., (1991), "Estimation and hypothesis testing of co-integration vectors in Gaussian vector autoregressive models", Econometrica, 59(6), pp. 1551-1580.

KAR, M., NAZLIOGLU, S. \& Huseyin AGIR, (2014), Trade Openness, Financial Development, and Economic Growth in Turkey: Linear and Nonlinear Causality Analysis, Journal of BRSA Banking and Financial Markets, Banking Regulation and Supervision Agency, 8(1), pp. 63-86.

Khan, M. A. \& Qayyum, A., (2007), "Trade, financial and growth nexus in Pakistan", Economic Analysis Working Papers, 6(14).

Korauš, A., Simionescu, M. \& Schönfeld, J., (2017), "The impact of monetary variables on the economic growth and sustainable development: case of selected countries", Journal of Security and Sustainability Issues, 6(3), p. 383-390.

Levine, R., (1997), "Financial development and economic growth: Views and Agenda", Journal of Economic Literature, 35(2), p. 688-726.

Levine, R., (2003), "Finance and Growth: Theory, Evidence, and Mechanisms", University of Minnesota and NBER.

Lewis, W. A., (1995), The theory of economic growth, London: Allen and Unwin.

Murthy, D. S., Patra, S. K. \& Samantaraya, A., (2014), "Trade Openness, Financial Development Index and Economic Growth Evidence from India (1971-2012)", Journal of Financial Economic Policy, 6(4), pp. 362-375.

National Bank of the Republic of North Macedonia, (2017), nbrm.mk, [Online] Available at: https://www.nbrm.mk/ns-newsarticle-monetarni-aggregati-en.nspx [Accessed 2207 2021].

Nwadike, G. C., Johnmary, A. K. \& Alamba, C. S., (2020), "Impact of Trade Openness on Nigerian Economic Growth: An Empirical Investigation, 1970-2011", Foreign Trade Review, $1(9)$.

Obeid, R. \& Awad, B., (2018), "The Effect of Trade Openness on Economic Growth in Jordan: An Analytical Investigation (1992-2015)", International Journal of Economics and Financial Issues, 8(2), pp. 219-226.

Popov, A., (2017), Evidence on finance and economic growth, European Central Bank, 2115. Quy-Toan, D. \& Levchenko, A., (2004), "Trade and Financial Development", World Bank.

Rajan, R. G. \& Zingales, L., (2001), "The Great Reversals: The Politics of Financial Development in the 20th Centry", NBER Working Paper, 8178.

Shahbaz, M., (2012), Does trade openness affect long run growth? Cointegration, causality and forecast error variance decomposition tests for Pakistan, Economic Modelling, Elsevier, 29(6), pp. 2325-2339.

Shahbaz, M. \& Rahman, M. M., (2012), "The Dynamic of Financial Development, Imports, Foreign Direct Investment and Economic Growth: Cointegration and Causality Analysis in Pakistan", Global Business Review, Volume 13(2), pp. 201-219. 
Simionescu, M., Balcerzak, A. P., Bilan, Y. \& Kotásková, A., (2018), "The impact of money on output in Czech Republic and Romania", Journal of Business Economics and Management, 19(1), pp. 20-41.

Simionescu, M., Popescu, J. \& Firescu, V., (2017), The relationship between gross domestic product and monetary variables in Romania, A Bayesian approach. Economic ResearchEkonomska Istraživanja, 30:1, pp. 464-476.

Sultana, N., (2018), "Impacts of money supply, inflation rate and interest rate on economic growth: A case of Bangladesh", JETIR, 5(10).

Tsaurai, K., (2017), "Investigating the Relationship between Financial Development, Trade Openness and Economic Growth in Argentina: A Multivariate Causality Framework", Acta Universitatis Danubius, Economica, 13(3).

Wajda-Lichy, M., Kawa, P., Fijorek, K. \& Denkowska, S., (2019), "Trade Openness and Financial Development in the New EU Member States: Evidence from a Granger Panel Bootstrap Causality Test", Eastern European Economics, 58(3), pp. 242-263.

Yucel, F., (2009), "Causal Relationships between Financial Development, Trade Openness and Economic Growth: The Case of Turkey", Journal of Social Sciences, 5(1), pp. 33-42.

Yugang, H., (2017), "A Study on the Relationship between Money Supply and Macroeconomic Variables in China", Mediterranean Journal of Social Sciences, Sciendo, 8(6), pp. 99-107. 